\title{
Michal Jasny*
}

iD https://orcid.org/0000-0002-5221-1251

\section{DOPING IN E-SPORTS. AN EMPIRICAL EXPLORATION AND SEARCH FOR SOCIOLOGICAL INTERPRETATIONS}

\begin{abstract}
Electronic sports is a new phenomenon in scientific research. Many issues within it have not been systematically analyzed. The use of artificial substances to improve human physical abilities is most often addressed in the context of deviation in sports. E-sports partially reflects sporting functionality, but in the area of doping and anti-doping control in video game competitions, it is difficult to delineate the boundary between what is allowed and what is forbidden. The aim of this work is to reconstruct the social assessment of doping in e-sports based on the attitudes and experience of fans and players. Most players accept the use of stimulants, such as energy drinks. Some of them also observe the use of prohibited substances during games. E-sports enthusiasts usually support anti-doping controls modeled on traditional sports and emphasize the importance of structural determinants of the issue, such as allowing the use of prohibited means.
\end{abstract}

Keywords: sociology of sport, doping, e-sports, video games.

\section{Introduction}

The essence of e-sports (electronic sports, or cybersports) is to develop one's skills and aim for the best performance in competitive gaming, which is based on electronically processed images generated by a computer program on a monitor, television screen or other multimedia device. E-sports have been bringing in rapidly increasing revenue every year. Currently, the global annual revenue amounts to over a billion dollars, with the US and China being the largest markets (New zoo 2019a). Every year, e-sports are becoming more popular. The current global audience amounts to 450 million fans (Newzoo 2019b), with Asia and the Pacific having decidedly the highest shares of fans.

The number of scientific studies concerning e-sports has been growing systematically for the last two decades. The year 2012 was a breakthrough point, with the number of publications doubling over a period of 12 months. The first paper on the subject in English was published in 2002, and approached the matter from

* $\mathrm{PhD}$, Department of Humanities and Social Sciences, University of Physical Education, ul. Marymoncka 34,00-968 Warszawa, e-mail: michal.jasny@awf.edu.pl 
a sociological viewpoint (Bryce, Rutter 2002). Later publications approached it from the viewpoint of sports science (Hemphill 2005), media studies, informatics, law or cognitive science. Reitman et al. (2019) identified 150 papers in English on e-sports published up to 2018; among these, 15 came from the field of sociology and as many as 37 came from the field of media studies. The first among the few Polish studies on e-sports was published in 2009 (Stępnik 2009 from the viewpoint of sports science; Dąbrowski 2011 with a sociology viewpoint).

The establishment and the subsequent gradual development of a new sociological subdiscipline - the sociology of e-sports - in the first two decades of the 21 st century, filled the gap in the scientific investigation of the sociocultural dimension of e-sports only slightly. The new research field contains many aspects that have yet to undergo a systematic analysis. One such aspect is the issue of doping in competitive gaming - bearing in mind that the boundary between what is allowed and what is forbidden is not always clear (Leszczyńska 2017).

\section{Doping in sport}

Doping is usually addressed in the context of deviation in sport (Leszczyńska 2017) and is defined as the use of artificial substances or methods to improve human physical capabilities and, consequently, sport performance (Gawroński, $\mathrm{Ziemb}$ a 2005). It is worth underlining that since 2017, Polish law has also treated competitions based on intellectual activity that are performed to achieve sport results as a form of sport. However, the Ministry of Sport and Tourism emphasised that the amended Act on Sport did not change the legal status of e-sports (i.e. it did not equate e-sports with traditional sport), although the act did raise the importance of disciplines that require building one's mental proficiency, which means that the law has opened up to include competitive gamers to a small extent.

A popular definition of doping is the one proposed by the World Anti-Doping Agency, according to which doping involves at least one breach of the antidoping regulations provided in the World Anti-Doping Code. This broadens the common understanding of doping as the use of illegal substances to include as little as the presence of illegal substances in the body of the sportsperson. While the problem of doping in sport is nothing new, it remains substantial. When compared to Polish publications, international literature encompasses a much wider spectrum of research subjects (Leszczyńska 2017).

Initially, the purpose of doping was not limited to performing better in sport competitions (Yesalis, Bahrke 2002; Rosen 2008; Mottram 2011). However, the rise in doping in the second half of the 20th century is thought to have originated from the transformations taking place in sport at the time:

1) the development of sport medicine;

2) growing investments into modern technologies applied in sport; 
3) growing pressure to break records due to the ongoing commercialisation and politicisation of sport (Waddington 2008).

A secondary effect of these changes was the instrumentalisation of doping related to the aforementioned politicisation: after World War II, competitive sport was treated as a tool of national propaganda, with success in sport supposedly indicating the superiority of a given political system and constituting a point of pride in international relationships (Wojtaszyn 2011). This led to the establishment and development of a doping system. Programmes created in totalitarian regimes involved supporting the sportspersons with any means available, with cooperation from the coaches, physicians, scientists and other members of the coaching staff. The most comprehensively described example is that of East Germany (Dennis 2015). However, the recently exposed doping in Russia confirms that the issue is still relevant (Altukhov, Nauright 2018).

An especially important growth factor for the popularity of doping was the aforementioned development of sport medicine; in particular, the role of physicians in the training process. It is difficult to imagine a contemporary sport training regime that does not involve medical support, the quality of which may affect a given sportsperson's physical advantage and competitive achievements. The success of sport medicine has caused an increase in the cases of non-medical use of particular substances. The physicians' engagement in matters related to doping is also significant (Waddington 2008).

Doping scandals involving sport celebrities have motivated the research. Some widely respected Olympic or World Championships medallists, who used to be role models for youth and other sportspersons, have been proven guilty of doping. Lance Armstrong and other cyclists who were accused of doping are the subjects of many sociological studies (see e.g. Brewer 2002; Connolly 2015).

Studies concerning anti-doping measures in sport tend to focus on the following:

1) the history of anti-doping;

2) current anti-doping regulations;

3) methods of combating doping (Malcolm 2008).

The core subject of the dispute is the effectiveness of the anti-doping system and the viability of combating doping at all (whether there are real chances of eliminating illegal practices from sport). In the face of more doping scandals, the possibility of legalising doping is being discussed. The arguments used by both the proponents and the opponents of doping are themselves subject to discussion (Schneider, Butcher 2000; Tamburrini 2000). The opponents underline that the substances and methods that improve physical performance are harmful to the sportspersons' health, regardless of whether they are used under medical supervision or not. Furthermore, doping is a breach of the standards and values established in sports, especially the rule of fair play. Doping indicates dishonesty and disrespect towards one's competitors. The sports organisations support this 
opinion. However, the proponents of legalising doping claim that combating this practice is pointless (Sas-Nowosielski 2006) due to the imperfections in the anti-doping system, the ineffectiveness and expense of doping controls, and the ineffectiveness of detecting new substances used by sportspersons. Furthermore, the proponents reject the notion of fair play, as well as the harmfulness of doping to health and the potential damage to the image of sport and celebrity sportspersons (Savulescu et al. 2004). The research on doping provides insight into contemporary sport and its problems (Leszczyńska 2017). Similar analyses conducted on e-sports may prove equally useful, and they could also reveal the differences and similarities between traditional sport and e-sports.

\section{Doping in e-sports}

The recognition of e-sports as a sport is problematic, yet the organized competitive playing of video games has seen a rise in many of the problems associated with conventional sport, such as match-fixing or using performance enhancing drugs (Holden et a1. 2017). In 2014, Bjoern Franzen, a former employee of a major video game company, drew the attention of the media to the issue of doping in e-sports, publicly admitting that it was an enormous problem. His blog post indicated that players took Piracetam, Methylphenidate, Modafinil, Selegiline, Propranolol, Ritalin and Adderall. These drugs (plus Vyvanse and Concerta) are prescribed to patients with Parkinson's disease, Alzheimer's and ADHD. They are supposed to improve focus and emotional control, as well as aiding relaxation or increasing stimulation before competitions (Cypryjański 2018).

The most infamous doping scandal in e-sports took place in 2015. In an interview during the Electronic Sports World Cup, Kory "Semphis" Friesen, a "Counter Strike" player and former member of the American organisation Cloud9, admitted that during the finals of the 2015 Intel Extreme Masters (IEM) in Katowice (Poland), he and his team were under the influence of Adderall (one of the drugs that Franzen had mentioned a year before). Evidence was to be found in the recordings of the players' conversations during the tournament, in which they were unusually stimulated and acted chaotically. They had problems following the agreed-on tactics. Following the scandal, the German company ESL Gaming, which was the organiser of the IEM, announced that it would conduct anti-doping tests and cooperate with WADA and NADA, the German anti-doping agency (Cypryjański 2018). At the time, the ESL tournament regulations prohibited the use of alcohol, narcotics and doping substances on pain of being banned from a tournament. However, it is unknown whether the players were tested for such substances. The current ESL regulations contain a slightly more elaborate clause on doping, which references a list of the substances and methods prohibited by WADA. After the Adderall scandal was exposed, actions were taken to improve awareness of 
the use of doping among video game players. However, the issue was addressed almost exclusively by ESL, which attempted to establish an anti-doping policy.

During the 2018 ESL One tournament, the Esports Integrity Commission (ESIC, formerly the Esports Integrity Coalition) published materials indicating that one in four hundred of the tested players used doping, including the use of prescription drugs (such as Adderall). Still, no conclusive information is available about doping among players from outside the global elite.

Anti-doping testing during e-sports tournaments is handled by Sporting Integrity (SI), an advisory company founded by Michele Verroken, former Director of Ethics and Anti-Doping at UK Sport. Verroken stated that dishonest players were increasingly opting out of taking Adderall in favour of other drugs. By cooperating with the players, coaches and organisations, SI aims to determine the substances that improve performance, which will help in updating and clarifying the tournament regulations. Research is being conducted on the effect of marijuana, among other substances. Verroken primarily conducts oral testing in this regard, as this, in her opinion, is the most effective method of detecting its use among players. Traditional sportspersons usually undergo urine tests (Baldwin 2019). However, online tournaments, in which the players participate remotely, are difficult to monitor. Furthermore, details on the anti-doping testing of professional gamers have not been publicised.

David Howman, former President of WADA, called e-sports a "Wild West", commenting on the lack of a uniform, consistently applied anti-doping policy for competitive gaming. The same issue was mentioned by the International Olympic Committee (IOC) with regard the proposal that some video games could potentially become Olympic disciplines. The committee representatives underlined that, currently, there is no organisation that oversees anti-doping testing in e-sports (Baldwin 2019). In 2018, the IOC organised an e-sports forum in Lausanne. However, the issue of doping was not raised. Officially, none of the international e-sports organisations and potential partners for WADA, such as ESL, the International Esports Federation (IESF) or the World Esports Association (WESA), have ever punished a player for doping. However, since 2013, IESF has been considered WADA's official signatory, thanks to the latter's approval of the IESF's proposed anti-doping policy (Van Hilvoorde, Pot 2016). Nonetheless, in order for the IOC to accept a given sports discipline (a video game) as an Olympic discipline, an international NGO responsible for managing the most important matters related to the game would have to be established. Furthermore, such an NGO would have to follow the Olympic Charter, including the World Anti-Doping Code (Jonasson, Thiborg 2010).

The e-sports community, despite the many similarities to sport (Thiel, John 2018; Zagała, Strzelecki 2019), almost never discusses the use of substances that improve the players' physical capacities and, consequently, their performance. A few international organisations (such as ESL and IESF) refer to the WADA 
regulations. In 2020, the Polish Anti-Doping Agency and two major e-sports associations signed a cooperation agreement to combat doping. The cooperation will focus on regulatory, educational and preventive actions, and the introduction of a full anti-doping testing programme. So far, however, little is known about any general or specific definitions of the allowable and prohibited substances and methods, or any rulings concerning anti-doping testing. Doping is a taboo subject to a certain extent, which makes any attempts at reconstructing the social assessment of doping in e-sports, and research on the attitudes and experiences of video game fans with respect to doping, very interesting and inspiring from the scientific point of view. Taking into account the difficulties with defining doping in e-sports and in applying WADA's list of prohibited substances and methods, the subject matter has been divided into three aspects in this study:

1) the use of allowed substances;

2) the use of prohibited substances (doping);

3) anti-doping testing.

\section{Research methods}

This study was explorative in nature. The data was collected using computerassisted web interviewing (CAWI) with non-probability sampling. The study participants comprised $n=241$ fans and players of video games, and e-sports activists who were members of the Esportowe Świry ("The Esports Loonies") discussion group on Facebook, which is the largest forum for sharing information, opinions and experiences about e-sports in Poland.

A total of 220 men (92\%) and 21 women aged between 14 and 34 were interviewed. The mean age of the respondents was 18 . The respondents declared that they played video games for between 2 and 90 hours weekly. The mean time spent playing was 22 hours, with a standard deviation of 16 hours. The respondents were fans of "League of Legends" (LoL) and "Counter-Strike: Global Offensive" (CS:GO), which regularly occupy the highest places in various rankings, both global and local, including Polish rankings, and in surveys conducted by the administrators of Esportowe Świry.

The participants of this study were asked to declare their involvement in e-sports (amateur or professional) according to the following three aspects: 1) the subjective perception of one's engagement; 2) membership in an organisation; and 3) earnings from e-sports. $14.5 \%$ of the respondents declared that they practised e-sports professionally. A similar share (15.8\%) reported membership in an e-sports organisation. $14.1 \%$ of the respondents declared that they earned money from e-sports. Therefore, the share of respondents who could be treated as professional e-sports players was similar between the three categories and did not exceed $15.8 \%$. The respondents were also asked whether they had participated in 
at least one e-sports tournament. $69.3 \%$ confirmed having participated as a player, which does not necessarily mean participation in major, prestigious tournaments such as the IEM finals, but also in local amateur events. Statistica 13.1 software was used for the statistical analysis of the obtained data. In bivariate analyses the Mann-Whitney $U$ and chi-squared tests were applied. Statistical significance was defined at $p<0.05$.

\section{Results and discussion}

\section{Allowed substances in e-sports}

Most of the e-sports fans who took part in the study (50.2\%) declared that allowed substances (containing caffeine, such as energy drinks) improve their performance in video games, $29.1 \%$ disagreed, and $20.7 \%$ answered that is was "hard to say". However, the respondents' belief about the effect of energy drinks and similar products on their performance, which is most likely based on popular opinion, has not been confirmed by a study conducted in the US. In that study, no beneficial effect of energy drinks on the psychomotor performance of professional LoL players was observed. Nonetheless, the authors of the study underlined that their research was only a starting point for wider and more detailed analyses (Thomas et al. 2019).

In the same study, $71.8 \%$ admitted that people from their social environment used allowed substances during video game competitions (with $47.3 \%$ indicating "many people" and $24.5 \%$ indicating "individual people"), while $20.7 \%$ declared that there were no such practices in their social environment, and $7.5 \%$ answered that is was "hard to say". A positive answer was selected by significantly more respondents who were members of an e-sports organisation $(86.8 \%)$ than those who considered themselves amateur sports players (69.0\%) (Table 1.). The most popular products were energy drinks (180 responses) and coffee (151 responses). Beer (55), herbs (27) and medicinal drugs (25) were also relatively popular. The manufacturers of alcoholic beverages also provide their logos and funds in e-sports competitions.

Why are video game players so fond of the allowed "boosters"? Let us use the finals of the LoL tournament as an example. The finals are made up of matches divided into five rounds, with each round lasting about 60 minutes. The players are only given a 5-minute break between the rounds, during which they usually discuss their tactics with their coach and use the bathroom. Thus, a match often lasts over five hours, with no time for a solid meal or a long rest. Furthermore, technical problems, involving for instance online connectivity issues, can considerably prolong the individual matches and consequently, the entire tournament. During matches, the players usually only have a water bottle (with no logos), which they sometimes use to smuggle in an isotonic drink. At the same time, products manu- 
factured by the sponsors of the tournament (e.g. energy drinks) are usually freely available. The circumstances encourage the use of readily-available and easy-touse allowed substances. However, such stimulation cannot exceed the limits imposed by the human body. Studies have reported cases of death from exhaustion, caused by dozens of hours of nearly uninterrupted play (Zhouxiang 2016).

In a commentary on Bjoern Franzen's report, the weekly New Scientist addressed the issue of unsupervised and excessive use of the allowed stimulants during tournaments, such as energy drinks, caffeine pills and other prescriptionfree products (Hodson 2014). The first dietary supplements for players that are designed to improve concentration and composure have already appeared in the US. They have no sugar or taurine content, but instead contain caffeine, choline, green tea extract, powdered ginger, 1-theanine and vitamins B3, B5, B6 and B12. The effects are not only an intense, temporary stimulation, but also a long-term boost to brain activity (Kotkowski 2019).

$58.5 \%$ of the participants in this study declared that video game competitions should not ban any of the currently allowed substances. Only $21.6 \%$ approved banning some of these substances, and $19.9 \%$ answered that it was "hard to say". Furthermore, $44.0 \%$ of the respondents declared that the players should not be tested for the use of allowed substances at all, 29.0\% approved of such tests and $27.0 \%$ selected the "hard to say" response.

\section{Prohibited substances (doping) in e-sports}

$10.8 \%$ of the participants in this study witnessed cases of players using prohibited (and sometimes illegal) substances during video game tournaments, such as cocaine, amphetamines or Adderall; among these responses, significantly more were received from the participants who earned money from e-sports $(20.6 \%)$ than those who considered themselves to be e-sports amateurs (9.2\%) (Table 1.). This data suggests that the scale of doping among the players from outside the global elite is considerably greater than among the elite players analysed by the ESIC.

$62.7 \%$ of the participants in this study had never heard about any preventive actions (e.g. on the part of tournament organisers) against doping in e-sports, while $37.3 \%$ had heard about such actions. Reports on preventive actions against doping in e-sports are rare. In 2017, ESL in cooperation with the ESIC commissioned a survey among players about their opinions on punishing cheating, match fixing and doping. The results of the survey led to the conclusion that tournament rules should be more restrictive. As early as in 2017, Dreamhack (the largest cyclical festival for fans of games and e-sports, encompassing events organised throughout the world) adopted the ESIC recommendations; however, the only changes introduced to the tournament regulations concerned match fixing (Irwin, Naweed 2018).

$68.5 \%$ of the participants in this study heard about someone who was punished for doping in e-sports, while $31.5 \%$ declared they had not heard about such 
cases. Thus, a considerable share of the participants did not know about any antidoping actions in e-sports, but had heard about players who were punished for doping. Are the changes being introduced to e-sports regulations concerning doping too insignificant, or even non-existent, because of the limitations imposed by organisational decentralisation and a desire to maintain revenue in this relatively profitable industry? Do organisations such as ESL or the ESIC, which are few in number but relatively active in their fight against doping, test the players and punish those who are caught doping, but choose not to share this information to avoid damaging the image of actors from the video game industry? It appears that only the cases that involve major tournaments or an elite player cannot be ignored or obscured.

The discrepancy between the obtained answers may also be caused by the respondents associating pharmacological doping with techno-doping (Schumacher 1999), which in e-sports usually involves "cheats", or breaking the rules set by the developer of a video game by modifying its mechanics (Consalvo 2007). Techno-doping in e-sports can also be analysed in the context of fyborgisation (a fyborg is a type of cyborg that temporarily merges the human body with technology, for the purpose of competitive sport) (Nosal 2017). Techno-doping also means the illicit improvement of the peripherals used to play a video game. Cheating in e-sports is mentioned much more frequently than doping substances.

In 2019, fans of CS:GO were shocked by a cheating scandal involving the Polish team Tajemnice Watykanu (Secrets of the Vatican), who were disqualified from the Polish ESL Championships eliminations. The scandal caused additional controversy due to ESL taking its time to issue a punishment, and the team's disqualification was not accompanied by any individual sanctions for the players. Adrian Kostrzębski, the spokesperson for ESL Poland, underlined that ESL believed in fair play, and that any suspected dishonesty was thoroughly investigated (Groenke 2019). However, the fundamental issue was that the tournament organisers did not cooperate with one another in this respect (Chomczyk 2019), which again results in questions about the presence and effectiveness of coordinated social controls for various forms of cheating in e-sports.

\section{Anti-doping testing in e-sports}

$44.4 \%$ of the participants in this study admitted that e-sports need to take more restrictive anti-doping actions (however, a significantly smaller share of the respondents who belonged to an e-sports organisation chose this answer [26.3\%] than the respondents who considered themselves e-sports amateurs [47.8\%]) (Table 1). $28.2 \%$ of the respondents would not support more restrictive anti-doping actions, and $27.4 \%$ answered that it was "hard to say". One would expect the e-sports fans, activists and players who participated in this study, especially those who were at least declarative members of an organisation, to be more willing 
to support fair play and, consequently, anti-doping actions. Institutional actors, such as the game developers or tournament organisers, have a certain influence on the players' behaviour and are able to control it, which means they are at least partially responsible for the players' dishonesty (including doping). This is one of the reasons why the inclusion of e-sports in the category of sport or video games is currently a subject of a heated legal discussion. In the local and international regulations, video game competitions usually have a special legal status (Reitman et al. 2019). Sanctioning e-sports within a given legislative system in order to construe it as sport could be beneficial; but simultaneously, it would also result in unwanted (yet unintentional) consequences due to e-sports being subject to the rules designed for traditional sport. It seems that the actors in the e-sports social world have reached a certain agreement (which does not concern combating doping) to maintain the convenient status quo of e-sports and assume that e-sports is moving a good way toward the classifications and regulations similar to those in traditional sport, even though the actions in this respect have so far only been proposed and still need legitimisation (Holden et al. 2017).

The participants in this study were asked whether, in their opinion, antidoping testing conducted under the supervision of a physician during e-sports tournaments would make the competition fairer. $60.6 \%$ of the participants agreed with this view, $19.9 \%$ disagreed and $19.5 \%$ answered that it was "hard to say". A similar number of participants (58.1\%) agreed that anti-doping tests such as a urine analysis would also make the competition fairer, while $23.3 \%$ disagreed and $18.7 \%$ answered it was "hard to say". A large share of the participants (a total of $39.4 \%$ for the former question and $42.0 \%$ for the latter) doubted whether the involvement of physicians in e-sports competitions would be effective. Does this mean that the social image of the e-sports player is not associated with the same physical "purity" or transparency as the image of the traditional sportsperson (or at least, not associated with the above to the same degree)? As with traditional sport, e-sports has the following characteristics:

1) it can be both competitive and casual (recreational);

2) it requires honing particular skills;

3) it has a substantial fan base;

4) it has its own regulations.

However, e-sports is unique in that it does not involve feats of sport in the traditional sense (i.e. supreme achievements of physical fitness) and is non-institutionalised. Success in e-sports usually does not require the players to achieve a physical advantage over their competitors (Jenny et al. 2017). As a result, extraordinary progress in medicine would be needed before it could shorten the thousands of hours involved in e-sports training with simply a few colourful pills.

The largest portion of the participants in this study (204 responses) stated that the use of doping in e-sports was usually motivated by the players wanting to win at all costs. However, many of the participants also indicated the lack of anti-dop- 
ing testing (68), tournament organisers neglecting anti-doping testing (56), social acceptance (the e-sports community does not view doping as wrong) (54), lack of punishment (53), and the low effectiveness or limitations of anti-doping testing (29). It is also worth noting that as many as 260 responses in total concerned the structural determinants of doping in e-sports. The lack of institutionalised central governance may not only be condoning, but potentially intensifying the use of performance enhancing drugs amongst the players (Holden et al. 2017).

Doping, both in traditional sport and e-sports, can be explained through the concept of a "positive deviation" caused by overconformity, which in turn stems from an indiscriminate acceptance of the fundamental values and rules of the sport ethos that include perfection, desire for victory, self-sacrifice and transgression. All of these values and rules are unambiguously positive for sportspersons, coaches, fans, activists and sponsors alike. However, their indiscriminate internalisation, combined with fanatical devotion, leads to players who strive for victory at all costs, disregarding their own health and the anti-doping regulations; in other words, the players are determined to "die for the cause" (Coakley, Hughes 1991).

The structural determinants of doping, such as tournament organisers neglecting anti-doping testing, can be interpreted through the categories of structural functionalism, the lack or ineffectiveness of social control mechanisms in the form of a coordinated anti-doping system, and the demobilisation of institutions, primarily game developers and tournament organisers. From the perspective of symbolic interactionism, social acceptance of doping substances can be explained through the concept of the social construction of deviation (Dziubiński 2019). Unless the fans, players and developers of video games start viewing doping as a problem, the users of these substances will never be labelled as social deviants, or if they are, the labelling will not have a significant impact.

Table 1. Statistically significant $(p<0.05)$ differences in respondents' responses concerning allowed and prohibited substances, and anti-doping testing in e-sports

\begin{tabular}{|c|c|c|c|}
\hline \multirow{2}{*}{$\begin{array}{l}\text { People in my environment use allowed } \\
\text { substances improving performance } \\
\text { in video games }\end{array}$} & Amateurs & $\begin{array}{c}\text { E-sports organisations } \\
\text { members }\end{array}$ & Total \\
\hline & $69.0 \%$ & $86.8 \%$ & $71.8 \%$ \\
\hline $\begin{array}{l}\text { E-sports need to take more restrictive } \\
\text { anti-doping actions }\end{array}$ & $47.8 \%$ & $26.3 \%$ & $44.4 \%$ \\
\hline \multirow{2}{*}{$\begin{array}{l}\text { I witnessed cases of using prohibited } \\
\text { or illegal substances during video } \\
\text { game tournaments }\end{array}$} & Amateurs & $\begin{array}{l}\text { Respondents earning } \\
\text { money from e-sports }\end{array}$ & Total \\
\hline & $9.2 \%$ & $20.6 \%$ & $10.8 \%$ \\
\hline
\end{tabular}

Source: Author's own study. 


\section{Closing remarks}

E-sports reflects the sport (or pseudo-sport) functionalities - this is evident from the professional players, teams, attire, coaches, managers, agents, leagues, tournaments, events (which frequently take place at traditional sport arenas), sponsorship agreements, player transfers, popular commentators and student scholarships, but also from the presence of match fixing, gender inequality and the use of doping substances (Funk et al. 2018; Jenny et al. 2017). However, the approach to doping seems to be different between e-sports and traditional sports (Baldwin 2019), which causes many issues, e.g. related to negotiating the recognition of video games as an Olympic discipline. Any further cooperation between e-sports organisations and the IOC will also have to involve WADA.

The results of this study are a starting point for further, more in-depth studies, which could expose general mechanisms responsible for doping in competitive playing of video games, and a clearer distinction between doping in traditional and electronic sports. The relatively large number of studies on doping in cycling can be referred to for guidance in planning and performing similar research on e-sports, which could encompass the following matters:

1) the specificities of doping in e-sports;

2) the conditions of professional players;

3) the institutionalisation of e-sports;

4) the motives behind the use of doping;

5) the stigmatisation of players who have been punished for doping or accused of cheating;

6) the functioning of the anti-doping system.

As with traditional sport, the media are the primary - and often the sole - source of information about doping (Leszczyńska 2017) in e-sports. Furthermore, doping in both traditional sport and e-sports is affected by the players who approach competitiveness as a source of profit. Sponsors do not want the players they support to be viewed as cheats for fear of losing their own reputation. The involvement of the authorities, organisations and various interest groups in matters related to doping and their interference in the anti-doping system without a doubt merits a detailed analysis (Leszczyńska 2017).

The institutional actors who combat doping in e-sports face many challenges. It seems that the use of artificial substances to improve physical capabilities in competitive gaming is predominantly underestimated, and only few e-sports activists are trying to bring this obscure but real problem to light. 


\section{Acknowledgements}

The author wishes to express his gratitude to Stanisław Słyk and Marcin Zarzycki for constant support and inspiration.

A scientific work financed by the Polish Ministry of Science and Higher Education from the science resources for year 2020 as part of the Science School SN No. 2 "The socio-humanistic school of physical culture research" of the University of Physical Education in Warsaw, Poland.

\section{Bibliography}

Altukhov S., Nauright J. (2018), The New Sporting Cold War: Implications of the Russian Doping Allegations for International Relations and Sport, "Sport in Society", no. 8(21), pp. 1120-1136.

Baldwin A. (2019), Targeted tests having an impact in esports, says Verroken, https://www.reuters. com/article/us-sport-doping/targeted-tests-having-an-impact-in-esports-says-verrokenidUSKCN1RT2D4 (accessed 2.10.2019).

Brewer B.D. (2002), Commercialization in Professional Cycling 1950-2001: Institutional Transformations and the Rationalization of "Doping", "Sociology of Sport Journal", no. 19(3), pp. 276-301.

Bryce J., Rutter J. (2002), Killing like a girl: Gendered gaming and girl gamers 'visibility, http:// www.digra.org/wp-content/uploads/digital-library/05164.00312.pdf (accessed 26.09.2019).

Chomczyk T. (2019), Afera cheaterska w ESL MP. Skoro dopuszczono się oszustwa, to dlaczego nie ma również kar indywidualnych?, https://esportmania.pl/big-stories/tajemnice-z-watykanuzdyskwalifikowane-z-udzialu-w-esl-mistrzostwach-polski/0wgwqh4 (accessed 23.10.2019).

Coakley J., Hughes R. (1991), Positive Deviance among Athletes: The Implications of Over Conformity to the Sport Ethic, "Sociology of Sport Journal", no. 8(4), pp. 307-325.

Connolly J. (2015), Civilising Processes and Doping in Professional Cycling, "Current Sociology", no. 63(7), pp. 1037-1057.

Consalvo M. (2007), Cheating: Gaining Advantage in Video Games, MIT Press, Cambridge.

Cypryjański M. (2018), E-sport: optymalizacja gracza, Helion, Gliwice.

Dąbrowski A. (2011), E-sport - przydawka czy coś więcej?, [in:] Ł. Rogowski, R. Skrobacki (eds.), Społeczne zmagania ze sportem, Wydawnictwo Naukowe Wydziału Nauk Społecznych Uniwersytetu im. Adama Mickiewicza, Poznań, pp. 117-139.

Dennis M. (2015), The East German Doping Programme, [in:] V. Møller, I. Waddington, J.M. Hoberman (eds.), The Routledge Handbook of Drugs and Sport, Routledge, AbingdonNew York, pp. 170-180.

Dziubiński Z. (2019), Dewiacje w sporcie wyczynowym, [in:] Z. Dziubiński, Z. Krawczyk, M. Lenartowicz (eds.), Socjologia kultury fizycznej, Akademia Wychowania Fizycznego Józefa Piłsudskiego, Warszawa, pp. 342-356.

Funk D.C., Pizzo A.D., Baker B.J. (2018), eSport management: Embracing eSport education and research opportunities, "Sport Management Review", no. 1(21), pp. 7-13.

Gawroński W., Ziemba A. (2005), Wybrane problemy dopingu a wspomaganie zdolności wysitkowych w sporcie, [in:] A. Jagier, K. Nazar, A. Dziak (eds.), Medycyna sportowa, Polskie Towarzystwo Medycyny Sportowej, Warszawa, pp. 501-519.

Groenke S. (2019), Tajemnice Watykanu odkryte. ESL thumaczy dyskwalifikację zespotu, https://eweszlo. pl/tajemnice_watykanu_odkryte_esl_tlumaczy_dyskwalifikacje_zespolu/(accessed 23.10.2019).

Hemphill D. (2005), Cybersport, "Journal of the Philosophy of Sport", no. 32(2), pp. 195-207. 
Hodson H. (2014), Esports: Doping is rampant, industry insider claims, https://www.newscientist. com/article/dn26051-esports-doping-is-rampant-industry-insider-claims/ (accessed 20.10.2019).

Holden J.T., Kaburakis A., Rodenberg R. (2017), The Future Is Now: Esports Policy Considerations and Potential Litigation, "Journal of Legal Aspects of Sport", no. 27(1), pp. 46-78.

Irwin S.V., Naweed A. (2018), BM'ing, Throwing, Bug Exploiting, and Other Forms of (Un)Sportsmanlike Behavior in CS:GO Esports, "Games and Culture", https://doi.org/10.1177/1555412018804952

Jenny S.E., Manning R.D., Keiper M.C., Olrich T.W. (2017), Virtual(ly) Athletes: Where eSports Fit Within the Definition of "Sport", "Quest", no. 69(1), pp. 1-18.

Jonasson K., Thiborg J. (2010), Electronic sport and its impact on future sport, "Sport in Society", no. 13(2), pp. 287-299.

Kotkowski Ł. (2019), Nie, Razer nie zrobit energetyka dla graczy. Razer wprowadza dedykowane odżywki do świata e-sportu, https://www.spidersweb.p1/2019/06/razer-respawn-dla-napoj-dla -graczy.html?fbclid=IwAR0blou7zSSIF26lvpC2euoQOKZYNCuRQExrqhzNCWD7pd3NF1 oEeiBK1hA (accessed 17.10.2019).

Leszczyńska A. (2017), Doping, [in:] H. Jakubowska, P. Nosal (eds.), Socjologia sportu, Wydawnictwo Naukowe PWN, Warszawa, pp. 11-24.

Malcolm D. (2008), Prohibition of Drugs, [in:] D. Malcolm, The SAGE Dictionary of Sport Studies, SAGE Publications, London, pp. 74-76.

Mottram D.R. (2011), A Historical Perspective of Doping and Anti-Doping in Sport, [in:] D.R. Mottram (ed.), Drugs in Sport, Routledge, Abingdon, pp. 21-34.

Newzoo (2019a), 2019 Global Esports Market, https://newzoo.com/key-numbers/ (accessed 26.09.2019).

Newzoo (2019b), 2018-2020 Global Esports Audience, https://newzoo.com/key-numbers/ (accessed 26.09.2019).

Nosal P. (2017), Technologia, [in:] H. Jakubowska, P. Nosal (eds.), Socjologia sportu, Wydawnictwo Naukowe PWN, Warszawa, pp. 231-241.

Reitman J.G.,Anderson-Coto M.J., Lee J.S., Wu M., Steinkuehler C.(2019), Esports Research: A Literature Review, "Games and Culture", no. 15(1), https://doi.org/10.1177/1555412019840892

Rosen D.M. (2008), Dope. A History of Performance Enhancement is Sports from the Nineteenth Century to Today, Praeger, Westport-London.

Sas-Nowosielski K. (2006), Glosa do dyskusji nad legalizacją dopingu w sporcie, "Sport Wyczynowy", no. 3-4, pp. 59-65.

Savulescu J., Foddy B., Clayton M. (2004), Why We Should Allow Performance Enhancing Drugs in Sport, "British Journal of Sports Medicine", no. 38(6), pp. 666-670.

Schneider A.J., Butcher R.B. (2000), A Philosophical Overview of the Arguments on Banning Doping in Sport, [in:] C. Tamburrini, T. Tännsjö (eds.), Values in Sport. Elitism, Nationalism, Gender Equality and the Scientific Manufacturing of Winners, E \& FN Spon, London, pp. 185-199.

Schumacher G. (1999), Science - No Thanks! Theses Against a Fruitless Venture, [in:] E. Müller, G. Zallinger, F. Ludescher (eds.), Science in Elite Sport, E \& FN Spon, London, pp. 36-43.

Stępnik A. (2009), E-sport z perspektywy teorii sportu, "Homo Ludens", no. 1, pp. 213-222.

Tamburrini C. (2000), What's Wrong with Doping?, [in:] C. Tamburrini, T. Tännsjö (eds.), Values in Sport. Elitism, Nationalism, Gender Equality and the Scientific Manufacturing of Winners, E \& FN Spon, London, pp. 200-216.

Thiel A., John J.M. (2018) Is eSport a "real" sport? Reflections on the Spread of Virtual Competitions, "European Journal for Sport and Society", no. 15(4), pp. 311-315.

Thomas C.J., Rothschild J., Earnest C.P., Blaisdell A. (2019), The Effects of Energy Drink Consumption on Cognitive and Physical Performance in Elite League of Legends Players, "Sports", no. 7(9), https://doi.org/10.3390/sports7090196 
Van Hilvoorde I., Pot N. (2016), Embodiment and Fundamental Motor Skills in eSports, "Sport, Ethics and Philosophy", no. 10(1), pp. 14-27.

Waddington I. (2008), Drugs, [in:] D. Malcolm, The SAGE Dictionary of Sport Studies, SAGE Publications, London, pp. 72-74.

Wojtaszyn D. (2011), Sport w cieniu polityki. Instrumentalizacja sportu w NRD, Oficyna Wydawnicza Atut - Wrocławskie Wydawnictwo Oświatowe, Wrocław.

Yesalis C.E., Bahrke M.S. (2002), History of Doping in Sport, "International Sports Studies", no. 24(1), pp. 42-76.

Zagała K., Strzelecki A. (2019), eSports Evolution in Football Game Series, "Physical Culture and Sport. Studies and Research", no. 83(1), pp. 50-62.

Zhouxiang L. (2016), From E-Heroin to E-Sports: The Development of Competitive Gaming in China, "The International Journal of the History of Sport", no. 33(18), pp. 2186-2206.

\title{
DOPING W E-SPORCIE. PRÓBA EKSPLORACJI EMPIRYCZNEJ I POSZUKIWANIE INTERPRETACJI SOCJOLOGICZNYCH
}

\begin{abstract}
Abstrakt. Na horyzoncie badań naukowych pojawiło się nowe zjawisko - sport elektroniczny. Wiele zagadnień w jego obrębie wciąż nie doczekało się usystematyzowanej analizy. Problem stosowania sztucznych substancji lub metod w celu poprawy fizycznych możliwości człowieka najczęściej podejmuje się w kontekście dewiacji w sporcie. E-sport częściowo odzwierciedla sportową funkcjonalność, ale w zakresie dopingu i kontroli antydopingowych we współzawodnictwie w grach wideo trudno postawić granicę między tym, co dozwolone, a tym, czego nie wolno robić. Celem prezentowanej pracy jest próba rekonstrukcji społecznej oceny zjawiska dopingu w e-sporcie na podstawie postaw oraz doświadczeń sympatyków i użytkowników gier. Graczy najczęściej charakteryzuje pozytywne nastawienie do stosowania substancji stymulujących, takich jak napoje energetyzujące. Niektórzy z nich w swoim otoczeniu obserwują przypadki stosowania niedozwolonych substancji podczas rozgrywek. Sympatycy e-sportu przeważnie popierają kontrole antydopingowe wzorowane na sporcie tradycyjnym i podkreślają znaczenie strukturalnych determinantów omawianego problemu, takich jak przyzwolenie otoczenia na stosowanie zabronionych środków.
\end{abstract}

Slowa kluczowe: socjologia sportu, doping, e-sport, gry wideo. 